\title{
Savings and Investment Behaviour of Young Adults: The Role of Financial Literacy and Parental Financial Behaviour
}

\section{Godfred Matthew Yaw Owusu}

Department of Accounting, University of Ghana Business School, Legon-Accra, Ghana

\section{Richard Ansong}

PricewaterhouseCoopers, Accra, Ghana

\section{Theodora Aba Abekah Koomson}

Department of Accounting, University of Ghana Business School, Legon-Accra, Ghana

\section{Annice Amoasa Addo-Yobo}

University of Ghana Business School, Department of Finance,

Legon-Accra, Ghana

\section{Correspondence:}

University of Ghana Business School

P. O. Box LG 78, Legon, Accra, Ghana.

Email address: gmyowusu@ug.edu.gh gmowusu@gmail.com

https://dx.doi.org/10.4314/ajmr. v27i1.5

\begin{abstract}
This study examines the savings and investment behaviour of young adults, their levels of financial literacy and ascertains whether financial literacy is an important predictor of savings and investment behaviour. Additionally, the study investigates the role of parental financial behaviour on financial literacy, savings and investment behaviour of young people. Using a survey-based approach, we collected data via a questionnaire from a sample of young undergraduate students from a large public university in Ghana. We employed the Covariance-Based Structural Equation Modelling technique to examine the hypothesized relationships of the study. The empirical results of the study based on a sample of 646 students show that financial literacy positively correlates with savings and investment behaviour of young adults. Moreover, we find parental financial behaviour to be an important predictor of the level of financial literacy of young adults and directly impacts on their savings and investment behaviour.
\end{abstract}

Key words: Household savings; investment behaviour; financial literacy; financial behaviour

\section{Introduction}

The relevance of savings and investment to the life of an individual is well established in the literature. Studies have shown that proper savings and investment culture is positively associated with financial well-being of individual households (Mandell, \& Klein, 2009; Oquaye, Owusu \& Bokpin, 2020; Prawitz, Garman, Sorhaindo, Neill, \& Kim, 2006) and has important implications on financial independence and stability of households (Loibl, 
Kraybill, \& DeMay, 2011). As surmised by Loibl et al. (2011), financial independence and stability of the household can be achieved only through repeated acts of savings. Indeed, beyond the individual household, savings and investment has been found to play a crucial role in the economic growth and development of a country.

The neoclassical theory of economic growth ${ }^{1}$ for instance posits that higher rate of savings and investment impacts positively on capital formation in a country which ultimately drive economic growth performance (Solow, 1956). The argument is that individual savings and investment particularly into financial assets constitute one of the important means by which financial intermediaries raises funds to meet the funding needs of firms in a country. The efficient allocation of such funds to firms in the most productive sectors of the economy ultimately improves the productive capacity of firms which can enhance the economic growth performance of the country. This proposition has been supported empirically by extant studies that associate the ability of a country to sustain its economic growth in the long run with the savings rate and investments of individual households (Harrod, 2016; Jonubi \& Abad, 2013; Loayza, Schmidt-Hebbel, \& Servén, 2000).

Interestingly, despite the stream of economic benefits associated with proper savings and investment behaviour both to the individual and the country at large, household savings and investments levels continue to decline in many parts of the world particularly in developing countries. The problem is even more pronounced in Africa with many Sub-Saharan countries recording the lowest savings rate in the world on a persistent basis (Africa Renewal, 2008). Given that most governments in developing countries have also reduced their investment into social support programmes with time (Agarwalla et al., 2015), the poor savings and investment behaviour of individuals should be of grave concern to the average individual in our contemporary time. This is because as Agarwalla et al. (2015) point out the shrink in government role in terms of direct financial support leaves the future financial security of individuals entirely in their own hands.

Studies into savings and investment behaviour of individuals have therefore become relevant in our time. Academic researchers in this area have particularly been interested in examining the dominant factors that drive the savings and investment behaviour of individuals. Two broad factors (economic and non-economic factors) have been identified in the literature to be the main drivers of household savings and investment decisions. Duflo \& Saez (2002) however, argue that the economic factors such as interest rate levels offer limited explanations to the savings and investment behaviour of individuals and emphasize the need for studies to investigate the effect of the non-economic factors. This study contributes to literature on the non-economic factors by investigating the effect of financial literacy on savings and investment behaviour of

${ }^{1}$ Commonly referred to as the Solow Growth Model

African Journal of Management Research (AJMR) 
young people. In addition, we examine the role of parental financial behaviour on savings and investment behaviour of young people. We argue that parents play a critical role in the socialization process and development of children and that parental financial behaviour could be an important predictor of financial behaviour of young people.

The empirical analysis presented in this study is useful for several reasons. First, focusing on young people is particularly relevant given that while the youth are considered to be the backbone of every nation, the manner in which young people obtain the skills to become financially independent has not been the focus of most studies (Shim, Xiao, Barber, \& Lyons, 2009). Second, the attempt to link parental financial behaviour to the savings and investment behaviour of their wards is also an important way of extending the literature on the determinants of savings and investment. This is so because, notwithstanding the fact that parents play an influential role in shaping the behaviour of children (Webley \& Nyhus, 2006), existing studies have usually ignored the role of parental influence on the savings and investment behaviour of children. Third, despite the fact that studies on household financial behaviours exist, only a few studies (Kiiza \& Pederson, 2006; Du Plessis, 2008) have provided empirical evidence to explain savings and investment behaviours from a developing country perspective. As Atkinson \& Messy, (2012) point out, there are wide differences in financial behaviours within and across countries in the world and hence, the need for studies in a different context. Given the low savings and investments levels in African countries, studies from such con- texts are useful in enhancing our understanding on this important subject.

The remaining sections of the paper are presented as follows: the next section reviews literature on savings and investment behaviour, financial literacy, parental financial behaviour and the predicted relationships among these key constructs of the study. This is followed by the research methodology, discussion of results followed by concluding remarks.

\section{Literature Review}

\section{Household Savings \& Investment Behaviour}

The term 'Saving' has been conceptualized to mean the commitment of sacrificing current consumption to allow for accumulation of capital that will yield additional return in the future (Gersovitz, 1988). In general terms savings is a precautionary measure of setting aside current financial resources to cater for future financial obligations as a result of random and unpredictable cash inflows. Savings, therefore, serve as a safety haven for individuals most especially in situations where income is not regular and remain one of the important means of attaining longterm goals in life.

Despite its importance, empirical studies have shown that most individuals spend more money than they could actually save (Birari \& Patil, 2014; Pritchard, Myers, \& Cassidy, 1989). This unfortunate trend in part has been attributed to the inability stick to savings plan by most individuals rather than the ability to save per se. The resultant effect is that people who practice savings usually save below the intended amount. It has been suggested in the literature that a person's ability to delay grati- 
fication $^{2}$ and exercise some level of selfcontrol is critical to maintaining a consistent savings plan (Webley \& Nyhus, 2006). Differences, however, exist among individuals in their ability to delay gratification.

The principle of investment on the other hand is the commitment of current financial resources in order to achieve higher gains in the future. As an activity, investment is usually carried out by individuals who have savings by committing these funds into capital assets, goods and services, having an expectation of a positive return in the long run (Pandey, 2004). Typical of any investment decision is the fact that the individual concern anticipates a certain return in future upon maturity of the investment product. Deciding on which investment product to purchase should therefore be backed by sound analysis of the costs and anticipated benefits associated with the various alternatives.

While an attempt has been made to distinguish savings from investment, it is common to find the two terms being used interchangeably in the literature as the two concepts go hand in hand. compared with savings, investment decisions therefore involve a thorough estimation and careful planning in order to achieve the muchneeded returns. Often, these decisions are supported by decision tools which require one to be financially literate. It is therefore expected that an individual with the right financial information will be able to make personal investment decisions which entails trying to allocate limited resources to various financial products and services that are competing for the same limited resources considering the risks and returns of the alternatives available.

\section{Financial Literacy, Savings and Investment Behaviour}

The President's Advisory Council on Financial Literacy (PACFL) in 2008 conceptualized a working definition of financial literacy as the "knowledge of basic economic and financial concepts, as well as the ability to use that knowledge and other financial skills to manage financial resources effectively for a lifetime of financial well-being" (Schwab et al., 2008). The Organisation for Economic Co-operation and Development (OECD), on the other hand, defines financial literacy as "a combination of awareness, knowledge, skill, attitude and behaviour necessary to make sound financial decisions and ultimately achieve individual financial wellbeing" (OECD, 2018, p. 4). By implication, a financially literate person is one who possesses the knowledge and skills to make sound financial decisions within the financial market. The role of financial literacy in making effective financial decisions has been well acknowledged in the literature. Generally prior studies (de Bassa Scheresberg, 2013; Huston, 2010; Perry, 2008) have found financial literacy to be an important predictor of financial outcomes including savings investment and debt behaviour.

Within the past decade significant amount of research interest has been generated on financial literacy due to its importance on financial behaviour of individuals. Most of these studies have focused on the extent of literacy and the outcomes of

\footnotetext{
${ }^{2}$ Being able to set aside something now in order to gain something more rewarding in the future
} 
financial literacy among a group of people within a particular domain. Hassan et al. (2014), for instance, investigated the impact of financial literacy on investment decisions of UAE citizens and found a significant relationship between them. Likewise, van Rooij, Lusardi and Alessie, (2011) found financial literacy to have an effect on stock market participation. Lusardi, Mitchell \& Mitchell (2011) in their study found an association between financial literacy and retirement planning. With respect to portfolio diversification, Guiso \& Jappelli, (2008) found measures of financial literacy to be highly correlated with the degree of portfolio diversification. Several other studies (Hastings \& Tejeda-Ashton, 2008; van Rooij, Lusardi \& Alessie, 2011; Hilgert et. al, 2003) also demonstrate that financial literacy affects an individual's ability to plan for retirement, manage and amass wealth, be involved in investment activities such as stock market participation and manage debt efficiently.

Notwithstanding the surge in research interest on financial literacy over the years, researchers have employed different scales in measuring the concept and the appear not to be a consensus to date. Proxies such as scores on knowledge level and experience from positive and negative financial behaviours have been used as measures of financial literacy (Oseifuah, 2010). This study employs the financial orientation (ORTOFIN) scale developed by Loix et al. (2005). This scale conceptualizes financial literacy as an individual's disposition towards finances characterized by personal interests and skills related to managing one's own finances effectively.
While the relevance of financial literacy on financial behaviour of individuals is widely acknowledged in the literature, the financial behaviour of parents has been cited to be particularly relevant for the financial behaviour of young people. The argument is that, through the socialization process, young people adopt their financial behaviour from their parents. The next section discusses the role of parental influence on financial behaviour of their wards.

\section{Role of Parental Financial Behaviour on Financial Behaviour of Children}

It has been argued that current financial behaviour of an individual is usually a reflection of past exposure and generally has implications on future behaviour. Shim, Barber, Card, Xiao, \& Serido, (2010) for instance, point out that the present financial behaviour of an individual in transition to adulthood has implications on his/her financial behaviour throughout adulthood stage. According to Drever et al. (2015) young people in making effective financial decisions such as managing resources, depend on earlier encounters they have experienced throughout life especially through the cognitive and conscious foundation laid by parents. Thus, despite the fact that behaviour is known to be an ever-changing phenomenon, there is a widely accepted notion that "past behaviour is the best predictor of future behaviour" (Ajzen, 1991, p. 201).This notion largely underscores the important role that parents play in the development process of their children. As an important agent in the socialization process of children, parental behaviour in all aspects of life including financials to a large extent affect the life of their children. This is because children tend to model their fi- 
nancial behaviour after their parents. In transitioning to become an adult, Schoeni $\&$ Ross (2005) indicate that that the youth rely more on the financial backing from their parents.

As argued by Gudmunson \& Danes (2011), while the formal means of learning plays a major role in influencing the behaviour of young people, it is also established that young people learn a lot through observation and imitation of older folks. This presupposes that the kind of financial behaviour their parents exhibit will indirectly affect their own financial behaviour as they grow. Financial behaviour refers to any human behaviour that is relevant to money management and include cash, credit, investment and saving behaviour. It covers a host of activities including savings, investment, debt management, retirement planning, insurance and the like.

Empirically, Webley \& Nyhus (2006) report that parental financial behaviour and financial orientation have a positive impact on current and future financial behaviour of their children. Again, Pinto (2005) examines credit cards usage among young adults and conclude that most young people learn more from parents than any other agent of socialization as far as credit card use is concern. According to Bernheim, Garrett \& Maki (2001) parents who encourage their children to save at a tender age using a bank account tend to save more than other individuals during adulthood. Similarly, Gudmunson \& Danes (2011) investigate the role of parental behaviour on financial literacy of children and conclude that parents play an influential role in the development of financial knowledge and skills of children.
The above findings from existing studies point to the fact that parents play a crucial role in shaping the financial behaviour of their wards. Over the years, financial management discourse among the youth have found parents to be the first source of external influence in shaping the financial attitudes and behaviours of the youth and are widely known to be the prime agents of financial socialization (Clarke, Heaton, Israelsen, \& Eggett, 2005).

Financial socialization refers to the series of activities that involve attaining and developing attitudes, values, knowledge and behaviours that improve the financial well-being of a person (Danes, 1994). Financial socialization process occurs through experience, beliefs, values, skills provided within a family setting. The family setting is an environment that breeds the initiations of rules and guidelines that shape behaviour and influence financial decision issues. Irrespective of the fact that socializations occur throughout life, the early stages in life of an individual is generally considered to be a key socialization period (Shim et al., 2010).

\section{Methodology}

Data collection technique, research instrument and measurement of constructs

The data for the study was collected from students pursuing undergraduate courses at University of Ghana Business School (UGBS). The questionnaires were administered during class sessions to afford every student present in class an equal chance of voluntary participation in the study. The questionnaire was divided into two sections. The first part focused on the demographic features of the respondent, including their age, gender, level of study etc. 
whilst the second component of the questionnaire focused on the main constructs of the study: savings, investment behaviour, financial literacy and parental financial behaviour. The constructs 'savings planning', investment behaviour and parental financial were each measured with a 7 -item scale developed by Kehiaian (2012). The construct financial literacy was operationalized using the orientation towards finances scale (ORTOFIN) developed by Loix et al. (2005). These instruments have previously been validated by other studies.

The indicators of each construct were measured on a 7-point Likert scale with 1 being strongly disagree and 7 strongly agree. While a 5-point Likert scale is often employed in most social science research, a 7-point Likert scale gives a wider range of likely responses helpful in getting variability in responses and thereby avoiding responses being cluttered at the extreme ends (Lee \& Lings, 2008).

\section{Data analysis}

The data collected was first analyzed using descriptive statistics and subsequently using inferential statistics. The descriptive analysis was done in Statistical Package for the Social Sciences (SPSS), where a numeric presentation of the features of the respondents and the sample data was generated in a table form. Subsequently, the study employed the Structural Equation Modelling (SEM) technique, specifically, The Co-Variance Based Structural Equation Modelling (CB-SEM) technique to examine the predicted relationships among the study constructs.

SEM enables researchers to evaluate mea- surement models and structural paths more efficiently and provides a platform for effective evaluation of the overall fitness of the study model and structural paths among constructs (Hair et al., 2012). SEM is particularly useful in assessing measurement models and structural paths involving multiple dependent variables and latent construct with multi-item indicator variables. The Co-Variance Based SEM was employed for this study using version 21 of the Analysis of Moment Structures (AMOS) software. The study follows a two-step approach: measurement model and structural model as employed in prior studies (Hanafizadeh et al., 2014).

\section{Measurement Model}

In assessing the measurement model, the indicators of each construct were initially subjected to a Confirmatory Factor Analysis (CFA) to determine the appropriateness of the indicators of the various constructs for inclusion in the structural model analysis. Based on the CFA results as shown in Table 1, three indicators of financial literacy were excluded from the analysis as they recorded factor loadings below the recommended threshold of 0.5 . Two indicators of savings planning and one indicator of parental financial behaviour equally loaded poorly and as such were also excluded from the final analysis. Next, the overall fitness of the model was assessed by relying on the fit indices: RMSEA, TLI, CFI, TLI, NFI, and CMIN/df as recommended by Byrne (2001). Results from this analysis as presented in Table 2 demonstrate that all the fit indexes used for the study met the specific thresholds recommended in existing studies. 
Table 1: Confirmatory Factor Analysis

\begin{tabular}{|c|c|c|c|c|}
\hline \multirow[t]{2}{*}{ Construct } & \multicolumn{4}{|l|}{ Factor } \\
\hline & Loadings & AVE & CR & CA \\
\hline Financial Literacy & & 0.72 & 0.83 & 0.85 \\
\hline I accurately plan my expenses & 0.85 & & & \\
\hline I keep track of general economic trends & 0.87 & & & \\
\hline I like to plan things & 0.70 & & & \\
\hline Investment Behavior & & 0.54 & 0.78 & 0.89 \\
\hline $\begin{array}{l}\text { I have invested money into at least one investment with } \\
\text { more risks than a savings account }\end{array}$ & 0.58 & & & \\
\hline $\begin{array}{l}\text { I use the principle of present and future value in my } \\
\text { investment calculations }\end{array}$ & 0.79 & & & \\
\hline $\begin{array}{l}\text { I use the concept of dollar cost averaging in my } \\
\text { investment planning }\end{array}$ & 0.66 & & & \\
\hline I use the power of diversification in my investment planning & 0.83 & & & \\
\hline I use the calculated risks in my investing strategies & 0.82 & & & \\
\hline I use the principle of risk vs. return & 0.80 & & & \\
\hline I feel comfortable investing my monies & 0.63 & & & \\
\hline Parental Financial Behavior & & 0.76 & 0.93 & 0.82 \\
\hline My parents budgeted on paper & 0.56 & & & \\
\hline My parents saved for emergencies & 0.84 & & & \\
\hline My parents made prudent financial choices & 0.83 & & & \\
\hline My parents invested some of their assets into stocks & 0.52 & & & \\
\hline My parents taught me good spending habits & 0.68 & & & \\
\hline $\begin{array}{l}\text { My parents paid off their debts within the repayment } \\
\text { scheduled plan }\end{array}$ & 0.53 & & & \\
\hline Savings Planning & & 0.55 & 0.71 & 0.76 \\
\hline $\begin{array}{l}\text { I save money before paying my routine expenses such as } \\
\text { airtime, food, bills etc. }\end{array}$ & 0.52 & & & \\
\hline $\begin{array}{l}\text { I use electronic deposit from my income to fund } \\
\text { savings account }\end{array}$ & 0.58 & & & \\
\hline $\begin{array}{l}\text { I normally have at least three months gross income } \\
\text { in an emergency fund }\end{array}$ & 0.74 & & & \\
\hline $\begin{array}{l}\text { I have a maintenance fund for repairs and other } \\
\text { periodic expenses }\end{array}$ & 0.74 & & & \\
\hline My average balance in my savings account normally goes up & 0.67 & & & \\
\hline
\end{tabular}

Legend: $\mathrm{AVE}=$ Average Variance Extracted; $\mathrm{CR}=$ composite reliability; $\mathrm{CA}=$ Cronbach Alpha. 
Table 2: Model fit indices for measurement model

\begin{tabular}{llll}
\hline Fit Indices & Accepted Values & Model Results & Remarks \\
\hline $\begin{array}{l}\text { Parsimony Normed } \\
\text { Fit Index (PNFI) }\end{array}$ & $>0.5$ (Mulaik et al., 1989) & 0.78 & Good \\
$\begin{array}{l}\text { Root Mean Square of } \\
\text { Approximation (RMSEA) }\end{array}$ & $<0.08$ (Byrne, 2001) & 0.06 & Good \\
Tucker Lewis Index (TLI) & $>.90$ (Bentler and Bonett, 1980) & 0.92 & Good \\
Comparative Fit Index (CFI) & $>0.90$ (Bentler, 1990) & 0.93 & Good \\
Goodness of fit Index (GFI) & $>0.90($ Chau, 1997) & 0.91 & Good \\
CMIN/DF & $<5.0$ (Bentler, 1990) & 3.35 & Good \\
\hline
\end{tabular}

\section{Reliability and Validity}

Tests for reliability of the constructs were conducted using the composite reliability (CR) and Cronbach Alpha (CA) scores. As shown in Table 1, the CR and CA scores for each constructs are between 0.71 and 0.93 which satisfy the recommended benchmark of 0.7 and above (Fornell \& David, 1981; Nunally, 1979). Validity of the constructs was assessed using the Convergent and Discriminant validity tests. Convergent validity was assessed using the Average Variance Extracted (AVE) whilst the discriminant validity test was conducted using the Fornell Lacker criterion which compares the squared inter-correlation co-efficient with the AVE. An AVE of 0.5 and above is deemed appropriate for convergent validity and the AVE score for each construct must be higher than the squared inter-correlation co-efficient for discriminant validity to be assured (Fornell \& David, 1981). The AVE values for the constructs as shown in Table 1 ranges from 0.54 to 0.76 , which is within the acceptable threshold. Results of the Fornell Lacker test as shown in Table 3 also demonstrate that discriminant validity is assured.

Table 3: Correlation and Correlation square matrix of latent variables

\begin{tabular}{lllll}
\hline & FO & IB & PFB & SP \\
\hline FO & 1 & 0.13 & 0.14 & 0.12 \\
IB & 0.36 & 1 & 0.04 & 0.25 \\
PFB & 0.38 & 0.21 & 1 & 0.14 \\
SP & 0.35 & 0.50 & 0.37 & 1 \\
\hline
\end{tabular}

NB: Values above the diagonal are squared correlations

\section{Results}

\section{Profile of the respondents}

The target population was business students pursuing undergraduate courses at University of Ghana Business School (UGBS). UGBS is an interdisciplinary faculty within the College of Humanities,
University of Ghana, with six departments: Accounting, Finance, Marketing, Human Resource, Public Administration and Health Service Management. It is a traditional aged public institution, Ghana's largest and premier business school which serves as mentoring insti- 
tution for several private universities in Ghana. A total of 700 questionnaires were administered to the respondents during classroom sessions. Out of this number, 646 valid responses were used for data analysis purposes.

Table 4 presents the demographic attributes of the respondents. More of the respondents were males than females. A little over half $(53 \%)$ of the respondents were males with the rest being females.
The population is largely youthful as close to $90 \%$ of the students were within the age bracket of 21-25. With regards to having a form of training in Finance, majority of the respondent group $(63.9 \%)$ indicated that they had received some form of education in Finance. Also, Final Year students constituted a larger proportion of the respondent group (33.1\%), with majority of the students (49.1\%) majoring in Accounting and Finance.

Table 4: Profile of the Respondents

\begin{tabular}{llll}
\hline Measure & Item & Frequency & Percentage (\%) \\
\hline \multirow{2}{*}{ Gender } & Male & 342 & 52.9 \\
& Female & 304 & 47.1 \\
\hline \multirow{2}{*}{ Age } & $17-20$ & 16 & 2.5 \\
& $21-25$ & 577 & 89.3 \\
& $26-30$ & 42 & 6.5 \\
& $31-35$ & 11 & 1.7 \\
\hline \multirow{2}{*}{ Training in Finance } & Yes & 413 & 63.9 \\
& No & 233 & 36.1 \\
\hline \multirow{2}{*}{ Major } & Accounting & 321 & 49.7 \\
& Finance & 164 & 25.4 \\
& Human Resource & 53 & 8.2 \\
& Public Administration \& & 49 & 7.6 \\
& Health Services Management & & 9.1 \\
& Marketing & 59 & 30.6 \\
& First Year & 142 & 29.4 \\
\multirow{2}{*}{ Level } & Second Year & 190 & 15.5 \\
& Third Year & 100 & 33.1 \\
\hline
\end{tabular}

Descriptive Statistics on Constructs An analysis of the respondents' views on the various constructs for the study is presented in Table 5. Financial literacy recorded an overall mean of 4.47. All indicators within the constructs had means above 5.0. This gives an indication that on average, the respondent group possesses high literacy levels in financial issues. Investment behaviour, on the other hand had an overall mean of 4.02. By implication, the respondent group exhibit sound investment behaviours. Moreover, parental financial behaviour scored highly with an overall score of 4.65 . This gives an indication that parents of the respondent 
group maintain good financial behaviour. Finally, savings planning recorded an overall mean 3.45 with all indicators recording a mean score above 3.0. Impliedly, majority of the respondents appear to have a good savings plan. The skewness and the kurtosis statistics indicate the values of all constructs are within the range of +2 and -2 implying that data for the constructs are generally normally distributed (Gravetter \& Wallnau, 2014).

Table 5: Mean, Standard Deviation, Kurtosis and Skewness Statistics

\section{Construct}

Financial Literacy

I never read the financial pages of my newsletter/newspaper 3.34

I try to keep track of general economic trends

I am not attracted to the financial part of my life

I regularly look for interesting investment opportunities for my money

I am interested in the evolution of currency rates

I accurately plan my expenses

I keep track of general economic trends

I like to plan things

4.47

4.54

2.50

4.89

4.77

5.14

4.89

5.70

\section{Mean Standard Kurtosis Skewness Deviation}

\section{Investment Behaviour}

I have invested money into at least one investment with

more risks than a savings account

I use the principle of present and future value in my

investment calculations

I use the concept of dollar cost averaging in my investment 3.35

planning

I use the power of diversification in my investment planning

I use the calculated risks in my investing strategies

I use the principle of risk vs. return

I feel comfortable investing my monies

\section{Parental Financial Behavior}

My parents budgeted on paper

My parents saved for emergencies

My parents made prudent financial choices

My parents invested some of their assets into stocks

My parents taught me good spending habits

My parents paid off their mortgage/loans prior to retiring.

My parents paid off their debts within the repayment scheduled plan

\subsection{2}

3.96

2.26

$-1.48$

0.02

$\begin{array}{llll}4.14 & 1.91 & -1.10 & -0.11\end{array}$

1.75

$-0.74$

0.35

3.84
4.02

1.87

$-1.03$

$-0.98$

0.01

$\begin{array}{ll}4.10 & 1.89\end{array}$

$-1.02$

$-0.13$

4.75

1.79

$-0.65$

\subsection{5}

3.88

5.12

5.12

1.94

$-1.15$

$-0.45$

$-0.15$

$-0.02$

1.78

$-1.24$

4.14

2.06

$-0.08$

5.25

4.22

4.83

1.73

$-0.19$

0.02

2.08

$-0.83$

$-1.20$

$-0.11$

\section{Savings Planning}

I save because my budget shows a positive disposable income

I save money before paying my routine expenses such as airtime, food, bills etc.

I use electronic deposit from my income to fund savings account

\subsection{5}

3.91

3.90

1.67

$-0.31$

$-0.80$

3.40

1.67

$-1.48$

$-0.24$

$3.40 \quad 1.65$

$-1.10$

0.03 
Table 5: Mean, Standard Deviation, Kurtosis and Skewness Statistics

\section{Construct}

\section{Mean Standard Kurtosis Skewness Deviation}

I normally have at least three months gross income in an emergency fund

I have a maintenance fund for repairs and other periodic expenses

My average balance in my savings account normally goes up I live for today not tomorrow

$\begin{array}{llll}3.14 & 1.56 & -0.74 & 0.19 \\ 3.30 & 1.63 & -1.03 & 0.10 \\ & & & \\ 3.90 & 1.52 & -0.98 & -0.23 \\ 2.59 & 1.75 & 0.72 & -0.77\end{array}$

\section{Structural model results}

Having confirmed the model fitness, reliability and validity of the constructs, the causal relationships between the exogenous and endogenous constructs based on the framework of the study as demonstrated in Figure 1 was ascertained. Results from the test suggest that Financial Literacy has a positive influence on savings $(\beta=0.26$, $p$-value $=0.000)$. Likewise, Finan-

Figure 1: Path Diagram

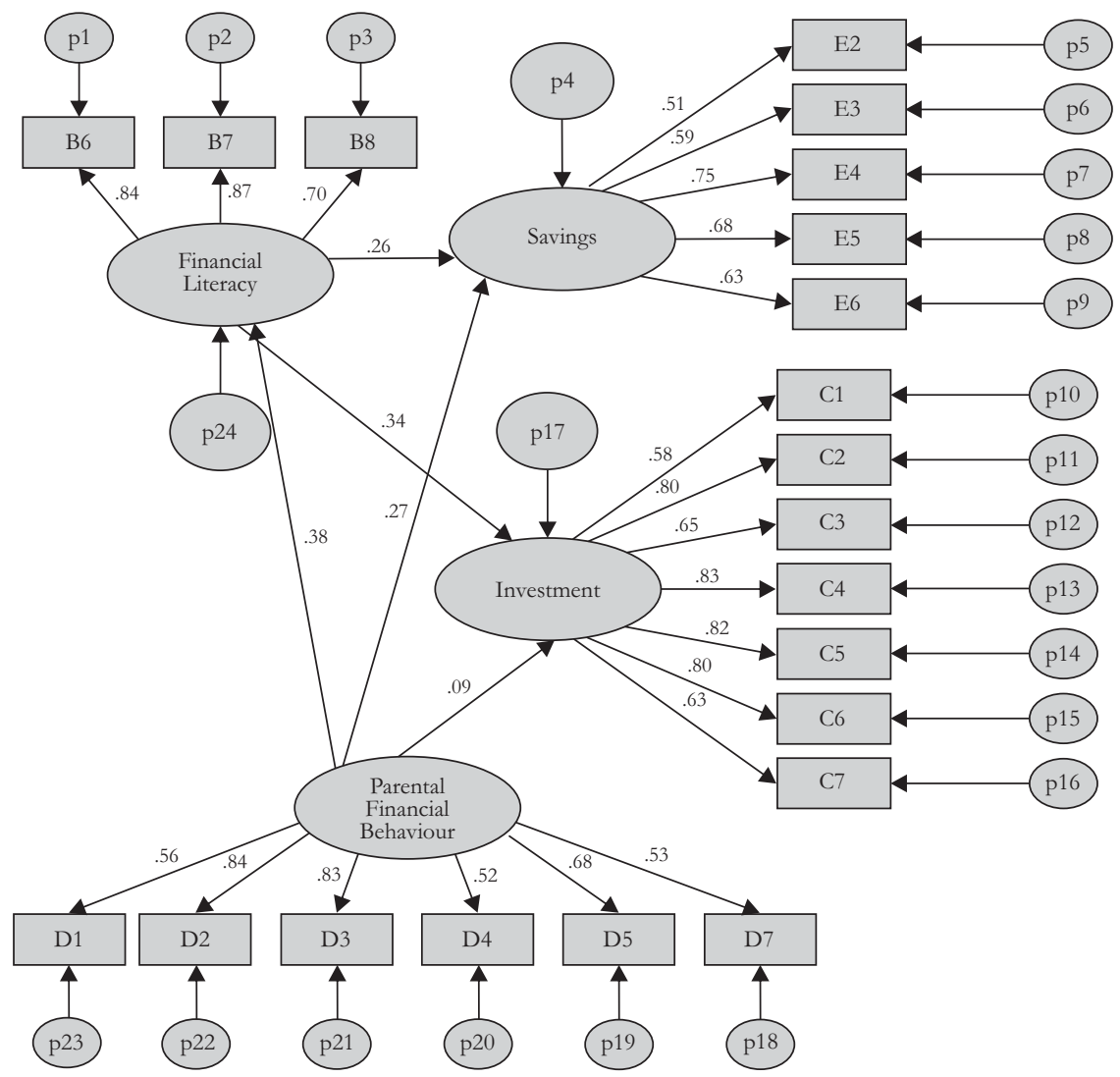


cial Literacy has positively related to investment $(\beta=0.34, p$-value $=0.000)$. Parental Financial Behaviour has a positive association with savings $(\beta=0.27, \quad p-$ value $=0.000)$ and investment $(\beta=0.09, \mathrm{p}$ value $=0.05)$. Also, Parental Financial Beha-viour is positively linked to financial literacy $(\beta=0.38$, $p$-value $=0.000)$.

Table 6: Standard coefficients and significance values for hypotheses

\begin{tabular}{lllll}
\hline Hypothesis & Path & $\begin{array}{l}\text { Standard } \\
\text { Co-efficient }\end{array}$ & P Value & Result \\
\hline H1 & Financial Literacy $\rightarrow$ Savings Planning & 0.26 & $* * *$ & Accepted \\
H2 & Financial Literacy $\rightarrow$ Investment Behavior & 0.34 & $* * *$ & Accepted \\
H3 & Parental Financial Behavior $\rightarrow$ Savings Behavior & 0.27 & $* * *$ & Accepted \\
H4 & Parental Financial Behavior $\rightarrow$ Investment Behavior & 0.09 & 0.05 & Accepted \\
H5 & Parental Financial Behavior $\rightarrow$ Financial Literacy & 0.38 & $* * *$ & Accepted \\
\hline
\end{tabular}

NB: $* * *=\mathrm{P}$ Value $<0.01$

\section{Discussion of results}

The current study examined the impact of financial literacy and parental financial behaviour on the savings and investment behaviour of young adults. The study further explored whether the financial literacy level of young adults is in any way influenced by parental financial behaviour. In line with the prediction of the study, financial literacy was found to be positively related to both savings and investment behaviour of the respondents. By implication, individuals who are financially proficient in knowledge and skills have good savings plan and positive disposition towards investment. Existing studies (Lusardi, 2008b; Mandell \& Klein, 2009; Murendo \& Mutsonziwa, 2017) have affirmed the existence of a positive relationship between financial literacy and savings behaviour. Murendo \& Mutsonziwa (2017) in particular document using data from a developing country setting that financial literacy increases the likelihood to save through both formal and informal savings mechanisms. Thus, in the context of developing economies financial literacy do not only affect the savings behaviour of individuals in the formal sector (who are usually in the minority) but also matters for the majority of individuals in the informal space who use informal savings portfolios.

Similarly, our finding of a positive relationship between financial literacy and investment behaviour is an indication that financially literate individuals tend to engage more in responsible investment behaviour than their peers. As explained by Grohmann, Kouwenberg, \& Menkhoff (2015) financial literacy increases significantly the chances of an individual investing in an investment product. Reference to stock market investment, Yoong (2011) for instance confirms that individuals with some degree of knowledge in financial matters are more likely to invest in stocks and mutual funds. Several empirical studies (Balloch, Nicolae, \& Philip, 2015; Hastings \& Tejeda-Ashton, 2008) generally support the assertion that financial 
literacy positively correlates with responsible investment behaviour. Taken together, our results suggest that an important way of promoting savings and investment habit among individuals is to enhance their levels of financial literacy. Policy initiatives meant to enhance literacy rates are therefore important in shaping the financial decisions of individuals.

The effect of parental financial behaviour on our variables of interest also yielded very satisfactory results. We observe from the results that parental financial behaviour has a positive effect on the financial literacy. This finding underscores the relevance of parental behaviour on the financial life of their wards. The ability of young people to appreciate financial concepts, plan their finances, the capacity to understand financial services and products in part could be linked with the exposure at home. Thus, the actions and inactions of parents play a crucial role in nurturing the financial knowledge and skills of their children. Being financially literate is therefore not obtained through the formal education system alone but could be developed informally through the socialization process. This finding is consistent with results from existing studies that associate parental financial behaviour with financial knowledge of their wards (Jorgensen \& Savla, 2010; Shim et al., 2010).

Lastly, we also find parental financial behaviour to be positively associated with both savings and investments behaviour of young adult. This implies that parental financial behaviour can influence the savings and investment decisions of their children both positively and negatively. Parents who exhibit good financial behaviour at home are more likely to influence their kids to be financially responsible when they become adults. While Grohmann et al. (2015) associate parental teaching for instance to be indirectly related to investment behaviour, our findings suggest the existence of a direct relationship between the two constructs. This finding is in line with other existing studies (Cude et al., 2006; Hira, Sabri \& Loibl, 2013; Webley \& Nyhus, 2006) that conclude that parental financial behaviour is an important predictor of savings and investment decisions of individuals.

\section{Conclusion}

In this paper we examine the savings and investment behaviour of young adults, their levels of financial literacy and ascertain whether financial literacy is an important predictor of savings and investment behaviour. We further examine the role of parental financial behaviour on financial literacy, savings and investment behaviour of young people. The evidence from our structural model analysis suggests that, parental financial behaviour has a positive influence on financial literacy, savings and investment behaviour of young people. Moreover, financial literacy is also observed to be a good predictor of the savings and investment behaviour of young people.

Given the increasing levels of debt among the youthful population across 
the globe coupled with the low savings and poor investment attitude among the youth, this study attempts to share some perspective on the factors that promote responsible savings and investment behaviour. In particular, we examine the effect of some non-economic factors (financial literacy and parental financial behaviour) on the savings and investment behaviours unlike most existing studies that focused predominantly on the influence of economic factors. The evidence provided in this study is important to policy makers interested in promoting savings and investment behaviour among its people, especially those from developing countries where savings and investment culture is poor. Based on the results of the study, we argue that an important way of encouraging people to save and invest at an early stage in life is to enhance their literacy levels in financial matters.

Given that the level of financial literacy in most developing countries is generally low, intervention policies such as financial educational campaigns could be implemented on a national scale to promote proper financial behaviour (such as savings and investment) among the youth. Besides formal intervention strategies such as financial educational campaigns, results of this study also demon- strate that the level of financial literacy younger folks could be enhanced through informal mechanisms such as parental behaviour. The findings of this study are therefore useful not to policy makers on the national stage alone but also to parents interested in securing the financial wellbeing of their children. As the results demonstrate the financial behaviour of parents plays a critical role in shaping the financial behaviour of their children. The results thus, emphasize the need for parents to recognize that they play a critical role in the financial socialization process of their wards. An important way of securing the financial future of children will be for parents to practice proper financial behaviour at home for their wards to emulate.

While these results provide some useful insights into the savings and investment behaviour of young people and the predictors of such behaviours, the sample used for the study though large was localized to one university and this may limit the extent of generalization. Again, the study considered the effect of only two non-economic factors: financial literacy and parental financial behaviour on savings and investment behaviour. These limitations provide important avenues for future studies.

behavior. Orgnizational Behavior and Human Decision Processes, 50, 179-211.

Atkinson, A., \& Messy, F. (2012). Measuring financial literacy: Results of the OECD/International Network on Financial Education (INFE)

Ajzen, I. (1991). The theory of planned 
Pilot Study. OECD Working Papers on Finance, Insurance and Private Pensions, No.

Bernheim, B. D., Garrett, D. M., \& Maki, D. M. (2001). Education and Savings: The LongTerm Effects of High School Financial Curriculum Mandates. Journal of Public Economics, (3), 1-44.

Balloch, A., Nicolae, A., \& Philip, D. (2015). Stock market literacy, trust, and participation. Review of Finance, 19(5), 1925-1963.

Berry, J., Karlan, D., \& Pradhan, M. (2018). The impact of financial education for youth in Ghana. World Development, 102, 71-89.

Birari, A., \& Patil, U. (2014). Spending \& Saving Habits of Youth in the City of Aurangabad. The SIJ Transactions on Industrial, Financial \& Business Management, 2(3), 158-165.

Bryne, B. M. (2001). Structural equation modeling with AMOS: Basic concepts, applications and programming. New Jersy, NJ: Lawrence Erlbaum Associates Inc.

Clarke, M. C., Heaton, M. B., Israelsen, C. L., \& Eggett, D. L. (2005). The acquisition of family financial roles and responsibilities. Family and Consumer Sciences Research Journal, 33(4), 321-340.

Cude, B., Lawrence, F., Lyons, A., Metzger, K., LeJeune, E., Marks, L., \& Machtmes, K. (2006). College Students and Financial Literacy: What They Know and What We Need to Learn. Eastern Family Economics and Resource Management Association, 102-109.

Danes, S. M. (1994). Parental Perceptions of Children's Financial Socialization. Financial Counseling and Planning, 5, 127-149.

de Bassa Scheresberg, C. (2013). Financial literacy and financial behavior among young adults: Evidence and implications. Numeracy, 6(2), 5 .

Drever, A. I., Odders-White, E., Kalish, C. W., Else-Quest, N. M., Hoagland, E. M., \& Nelms, E. N. (2015). Foundations of financial well-being: Insights into the role of executive function, financial socialization, and experience-based learning in childhood and youth. Journal of Consumer Affairs, 49(1), 13-38. du Plessis, G. (2008). An Exploration of the Determinants of South Africa 's Personal Savings Rate - Why do South African Households Save so Little?, (November), 1-129.

Duflo, E., \& Saez, E. (2002). Participation and investment decisions in a retirement plan: The influence of colleagues' choices. Journal of Public Economics, 85(1), 121-148.

Fornell, C., \& David, L. F. (1981). Structural Equation Models With Unobservable Variables and Measurement Error : Algebra and Statistics, 18(3), 382-388.

Gersovitz, M. (1988). Saving and development. Handbook of Development Economics, 1(1986), 381-424.

Gravetter, F. J., \& Wallnau, L. B. (2014). Introduction to the t statistic. Essentials of Statistics for the Behavioral Sciences, 8, 252.

Grohmann, A., Kouwenberg, R., \& Menkhoff, L. (2015). Childhood roots of financial literacy. Journal of Economic Psychology, 51, 114133.

Gudmunson, C. G., \& Danes, S. M. (2011). Family Financial Socialization: Theory and Critical Review. Journal of Family and Economic Issues, 32(4), 644-667.

Guiso, L., \& Jappelli, T. (2008). Financial Literacy and Portfolio Diversification. EUI Working Papers.

Hair, J. F., Sarstedt, M., Ringle, C. M., \& Mena, J. A. (2012). An assessment of the use of partial least squares structural equation modeling in marketing research. Journal of the Academy of Marketing Science, 40(3), 414-433.

Hanafizadeh, P., Behboudi, M., Koshksaray, A. A., \& Tabar, M. J. S. (2014). Mobile-banking adoption by Iranian bank clients. Telematics and Informatics, 31(1), 62-78.

Harrod, R. F. (2016). An Essay in Dynamic Theory. The Economic Journal, 49(193), 49-33.

Hassan, H. A., Tamimi, A., Anood, A., Kalli, B., Al-tamimi, H. A. H., Anood, A., \& Kalli, B. (2014). Financial literacy and investment decisions of UAE investors.

Hastings, J. S., \& Tejeda-Ashton, L. (2008). Financial Literacy, Information, and Demand 
Elasticity: Survey and Experimental Evidence from Mexico. NBER Working Paper.

Hira, T. K., Sabri, M. F., \& Loibl, C. (2013). Financial socialization's impact on investment orientation and household net worth. International Journal of Consumer Studies, 37(1), 29-35.

Huston, S. J. (2010). Measuring Financial Literacy. The Journal of Consumer Affairs, 44(2), 296-316.

Jappelli, T., \& Padula, M. (2013). Investment in financial literacy and saving decisions. Journal of Banking and Finance, 37(8), 2779-2792.

Jonubi, A., \& Abad, S. (2013). The impact of financial literacy on individual saving: an exploratory study in the Malaysian context. Transformations in Business \& Economics, 12(1), 28.

Jorgensen, B. L., \& Savla, J. (2010). Financial Literacy of Young Adults : The Importance of Parental Socialization, 59(4), 465-478.

Kehiaian, S. E. (2012). Factors and behaviors that influence financial literacy in US households. Nova Southeastern University.

Kiiza, B., \& Pederson, G. D. (2006). Savings and asset allocation of households in Uganda. Agricultural finance review, 66(2), 283295.

Lee, N., \& Lings, I. (2008). Doing business research: A guide to theory and practice. Sage.

Loayza, N., Schmidt-Hebbel, K., \& Servén, L. (2000). Saving in developing countries: An overview. The World Bank Economic Review, 14(3), 393-414.

Loibl, C., Kraybill, D. S., \& DeMay, S. W. (2011). Accounting for the role of habit in regular saving. Journal of Economic Psychology, 32(4), 581-592.

Loix, E., Pepermans, R., Mentens, C., Goedee, M., \& Jegers, M. (2005). Orientation Toward Finances: Development of a Measurement Scale. Journal of Behavioral Finance, 6(4), 192-201.

Lusardi, A., \& Mitchell, O. S. (2008). Planning and financial literacy: How do women fare? American Economic Review, 98(2), 413-417.

Lusardi, A., Mitchell, O. S., \& Curto, V. (2010). Financial Literacy among the Young. The
Journal of Consumer Affairs, 44(2), 358-380.

Lusardi, A., \& Mitchell, O. S. (2011). Financial literacy and planning: Implications for retirement wellbeing (No. w17078). National Bureau of Economic Research.

Mandell, L., \& Klein, L. S. (2009). The Impact of Financial Literacy Education on Subsequent Financial Behavior. Journal of Financial Counseling and Planning, 20(206), 15-24.

Murendo, C., \& Mutsonziwa, K. (2017). Financial literacy and savings decisions by adult financial consumers in Zimbabwe. International Journal of consumer studies, 41(1), 95-103.

Nunnally, J. C. (1978). PsychometricTheory. McGraw-Hill, NewYork, NY.

OECD (2018), OECD/INFE Toolkit for Measuring Financial Literacy and Financial Inclusion.

Oquaye, M., Owusu, G.M.Y. and Bokpin, G.A. (2020). The antecedents and consequence of financial well-being: a survey of parliamentarians in Ghana. Review of Behavioral Finance, Vol. ahead-of-print No. ahead-ofprint.

Oseifuah, K. E. (2010). Financial literacy and youth entrepreneurship in South Africa. African Journal of Economic and Management Studies, 1(2), 164-182.

Perry, G. V. (2008). Is Ignorance Bliss ? Consumer Accuracy in Judgments about Credit Ratings. The Journal of Consumer Affairs, 42(2), 189-205.

Pinto, M. B. (2005). Information Learned From Socialization Agents: Its Relationship to Credit Card Use. Family and Consumer Sciences Research Journal, 33(4), 357-367.

Prawitz, A. D., Garman, E. T., Sorhaindo, B., Neill, B. O., \& Kim, J. (2006). In Charge Financial Distress / Financial Well-Being Scale : Development, Administration, and Score Interpretation, (732), 34-50.

Pritchard, M. E., Myers, B. K., \& Cassidy, D. J. (1989). Factors associated with adolescent saving and spending patterns. Adolescence, 24(95).

Schoeni, R. F., \& Ross, K. E. (2005). Material assistance from families during the transition to 
adulthood. University of Chicago Press.

Schwab, C., Iannicola Jr, D., Beck, T., Hira, T., Bryant, J. H., Parker, J., ... \& Dawson, C. (2008). President's Advisory Council on Financial Literacy. Annual Report to the President. Washington: The Department of the Treasury.

Shim, S., Barber, B. L., Card, N. A., Xiao, J. J., \& Serido, J. (2010). Financial Socialization of First-year College Students: The Roles of Parents, Work, and Education. Journal of Youth and Adolescence, 39(12), 1457-1470.

Shim, S., Xiao, J. J., Barber, B. L., \& Lyons, A. C. (2009). Pathways to life success: A conceptual model of financial well-being for young adults. Journal of Applied Developmental Psycho$\log y, 30(6), 708-723$.

Solow, R. M. (1956). A contribution to the theory of economic growth. The Quarterly Journal of Economics, 70(1), 65-94.

van Rooij, M., Lusardi, A., \& Alessie, R. (2011). Financial literacy and stock market participation. Journal of Financial Economics, 101(2), 449-472.

Webley, P., \& Nyhus, E. K. (2006). Parents' influence on children's future orientation and saving. Journal of Economic Psychology, 27(1), 140-164.

Yoong, J. K. (2011) Financial illiteracy and stock market participation: Evidence from the RAND American life panel. In: Mitchell, O. S., Lusardi, A. (eds) Financial literacy: implications for retirement security and financial marketplace. Oxford University Press, Oxford, pp 76-97 